\title{
IAMJ
}

INTERNATIONAL

AYURVEDIC

MEDICAL JOURNAL

\section{RANDOMISED CONTROLLED CLINICAL STUDY OF KUSHTADI YONI VARTI ON CERVICAL EROSION}

\author{
Sindhu Umesh ${ }^{1}$, Jayasudha G. $C^{2}$, Ramesh $M^{3}$ \\ ${ }^{1}$ Assistant Professor, Dept of PTSR, Sri Dharmasthala Manjunatheshwara Institute of Ayurveda and \\ Hospital, Bangalore, Karnataka, India \\ ${ }^{2}$ Professor, Dept of PTSR, Rajeev Institute of Ayurveda Medical science and Research Centre, Hassan, \\ Karnataka, India \\ ${ }^{3}$ Former Professor and HOD, Dept of PTSR, Government Ayurvedic Medical College, Bangalore, \\ Karnataka, India
}

Corresponding Author: vedasindhu@gmail.com

https://doi.org/10.46607/iamj01p6012021

(Published online: November 2021)

Open Access

(C) International Ayurvedic Medical Journal, India 2021

Article Received:26/10/2021 - Peer Reviewed:07/11/2021 - Accepted for Publication:08/11/2021

Check for updates

\begin{abstract}
Cervical Erosion may present with symptoms like vaginal discharge or serious problems of female infertility and thus gains importance in the gynaecological practice ${ }^{1}$. This entity is correlated with GarbhashayaMukhaGata Vrana (GGV), of Vatakaphaja variety. In the present study, Kushtadi YoniVarti (KYV) ${ }^{2}$ is proposed as a local treatment for Cervical Erosion. The present study has two groups: Group A:30 patients, were treated with Kushtadi Yoni Varti, followed by Sukhoshna Jala Prakshalana for 7 consecutive days. Group B:30 patients were advised with Pathya and apathy for 7 days. The Follow up for both groups were on $14^{\text {th }}$ Day and $21^{\text {st }}$ Day. The results were analysed statistically with paired and unpaired t-test. On comparing the two groups, it was found that the efficacy of treatment in Group A was better than the efficacy of treatment in Group B with reference to amount and odour of discharge, appearance and degree of erosion.
\end{abstract}

Keywords: Cervical Erosion, Kushtadi Yoni Varti, GarbhashayaMukhaVrana, PAP Smear. 


\section{INTRODUCTION}

The unopposed oestrogen in females leads to the destruction of squamous epithelial tissue of the cervix and replacement by columnar epithelial tissue resulting in Cervical Erosion which is clinically evident by excessive mucoid discharge per vagina. With reference to the physical signs and symptoms exhibited by this pathological process, it can very well be correlated to the concept of Vatakaphaja Vrana characterized by Shweta, Pichchila Srava simulates to the specific symptom of white mucoid discharge per vagina in the case of Cervical Erosion. Karnini Yoni Vyapat is the clinical correlation. The local vaginal treatments which are more effective and act faster are more preferred due to the ease of use. Thus, Kushtadi Yoni Varti, mentioned in Karnini Yoni Vyapat, which is Vata Kaphaja was selected for the treatment of Cervical erosion.

\section{OBJECTIVE}

1. To evaluate the efficacy of Kushtadi Yoni Varti in Cervical Erosion.

2. To study the mode of action of Kushtadi Yoni Varti on Cervical Erosion

\section{METHODOLOGY}

This clinical study was carried out on 60 patients who attended the OPD and IPD sections of Prasooti Tantra and Stree Roga Department, SKAMCH \&RC, Bangalore.

\section{Inclusion criteria}

- Diagnosed cases of Cervical Erosion

- Married female patients between the age group of $18-45$ yrs.

\section{Exclusion criteria}

- Pregnant women

- Puerperal erosion

- Local pathology of the cervix interferes with the treatment.

- Systemic disorders which interfere with the course of treatment

\section{Assessment criteria with gradation.}

Signs and symptoms will be assessed using the following parameters along with grading from 0 to 3

\section{ASSESSMENT CRITERIA}

\section{Subjective Criteria:}

1. Yoni Srava / (Vaginal Discharge)

2. Gandha of Srava (Odour of Discharge)

3. Yoni Kandu (Vaginal Itching)

4. Low back pain (Kati Shoola)

5. Lower abdominal pain

6. Burning micturition

7. Dyspareunia-

\section{Objective Criteria: -}

1. Amount of Discharge

2. Odour of discharge

3. Evidence of pruritis

4. Cervical Tenderness

5. The extent of Erosion (\% Scale system)

6. Appearance of Erosion

7. Degree of Erosion

8. Bleeds on touch

\section{Investigations}

- $\quad$ Blood $-\mathrm{Hb} \%, \mathrm{TC}, \mathrm{DC}, \mathrm{ESR}, \mathrm{RBS}$

- Urine examination (Albumin, Sugar, Micro)

- Vaginal pH

- Pap smear

- Urine Pregnancy Test (UPT), (in patients with h/o amenorrhoea)

\section{STUDY DESIGN}

A controlled clinical study with pre-test and post-test analysis was conducted on 60 randomly assigned patients with signs and symptoms of Cervical Erosion.

INTERVENTION Diagnosed patients were randomly assigned into two groups.

Group A:30 diagnosed patients with Cervical Erosion, were treated with Kushtadi YoniVarti, following all aseptic measures, followed by Sukhoshna Jala prakshalana for 7 consecutive days. (Varti was administered in the posterior fornices of the Vagina for 2 hours each day, starting from the $7^{\text {th }}$ day of the menstrual cycle for 7 days.)

Group B:30 diagnosed patients of Cervical Erosion advised with Pathya and Apathya for 7 days

\section{For Both Groups:}

Pre-Test- $1^{\text {st }}$ Day

Post Test- $7^{\text {th }}$ Day 
Follow up $14^{\text {th }}$ Day and $21^{\text {st }}$ days.

\section{OBSERVATIONS}

The data recorded are presented under the following criteria:
- Rogi Pareeksha

- Roga Pareeksha

- Prayoga Shaala Pareeksha (PAP Smear)

\section{Rogi Pareeksha}

Age group of 18- $26 \mathrm{yrs}$.

Mixed diet

Consuming madhura rasa

Abhishyandi ahara like curd daily

Divaswapna.

Kapha vata Prakruti

Multigravida

FTND

Intercourse 3 to 4 times per week

\section{Roga Pareeksha}

\begin{tabular}{|l|l|l|}
\hline $50 \%$ & Kaphakara nidana & $56.66 \%$ \\
\hline $75 \%$ & White mucoid discharge & $90 \%$ \\
\hline $48.33 \%$ & Nebothian Follicle & $60 \%$ \\
\hline $65 \%$ & Kandu & $50 \%$ \\
\hline $56.66 \%$ & The extent of erosion in 50\% of patients & $26-50 \%$ \\
\hline $38.33 \%$ & The appearance of erosion in 50\% of patients & Degree 2 \\
\hline $80 \%$ & Degree of erosion in 70\% of patients & Degree 2 \\
\hline $65 \%$ & Prayoga Shaala Pareeksha & \\
\hline $50 \%$ & Changes in cellular Pattern & $78.34 \%$ \\
\hline
\end{tabular}

\section{RESULTS}

The study showed highly significant results among patients in Group A in terms of relief in amount and odour of discharge, itching, Low backache and lower abdomen pain, Cervical tenderness, appearance and degree of erosion. The study showed just significant results in Group B in terms of amount and odour of discharge, Low backache and lower abdomen pain and non-significant result in Cervical tenderness, appearance and degree of erosion. On comparing the two groups, it was found that the efficacy of treatment in Group A was better than the efficacy of treatment in Group B with reference to amount and odour of discharge, appearance and degree of erosion.

Statistical Results Within groups and Between 2 groups

\begin{tabular}{|c|c|c|c|c|c|}
\hline \multicolumn{6}{|c|}{ Subjective Criteria } \\
\hline & & & Group A & Group B & B/w Grp A - Grp B \\
\hline \multirow[t]{3}{*}{1.} & \multirow{3}{*}{$\begin{array}{l}\text { Yoni Srava } \\
\text { (Vaginal Discharge) }\end{array}$} & $\mathrm{T}$ value & 17.02 & 2.44 & 8.56 \\
\hline & & P Value & $<0.001$ & $<0.05$ & $<0.001$ \\
\hline & & Result & HS & JS & HS \\
\hline \multirow[t]{3}{*}{2.} & \multirow[t]{3}{*}{ Odour of discharge } & $\mathrm{T}$ value & 4.11 & 2.17 & 3.8 \\
\hline & & P Value & $<0.001$ & $<0.01$ & $<0.001$ \\
\hline & & Result & HS & JS & HS \\
\hline \multirow[t]{4}{*}{3.} & \multirow[t]{4}{*}{ Vaginal itching } & T value & 3.66 & 1.6 & 1.58 \\
\hline & & P Value & $<0.001$ & $<0.1$ & $<0.1$ \\
\hline & & Result & HS & NS & NS \\
\hline & & Result & JS & JS & NS \\
\hline \multicolumn{6}{|c|}{ Objective Criteria } \\
\hline \multirow[t]{3}{*}{1.} & \multirow[t]{3}{*}{ Amount of Discharge } & $\mathrm{T}$ value & 4.6 & 2 & 1.1 \\
\hline & & P Value & $<0.001$ & $<0.1$ & $<0.1$ \\
\hline & & Result & HS & NS & NS \\
\hline \multirow[t]{3}{*}{5.} & \multirow[t]{3}{*}{ Extent of Erosion } & $\mathrm{T}$ value & 3.28 & 0.87 & 0.86 \\
\hline & & P Value & $<0.05$ & $<0.1$ & $<0.1$ \\
\hline & & Result & JS & NS & NS \\
\hline
\end{tabular}




\begin{tabular}{|l|l|l|l|l|l|}
\hline 6. & Appearance of Erosion & T value & 7.5 & 1.11 & 4.2 \\
\hline & & P Value & $<0.001$ & $<0.1$ & $<0.001$ \\
\hline & & Result & HS & NS & HS \\
\hline 7. & Degree of Erosion & T value & 7.5 & 1.18 & 4.6 \\
\hline & & P Value & $<0.001$ & $<0.1$ & $<0.001$ \\
\hline & & Result & HS & NS & HS \\
\hline 8. & Bleed on Touch & T value & 3.32 & 0.6 & 0 \\
\hline & & P Value & $<0.5$ & $<0.1$ & $<0.1$ \\
\hline & & Result & JS & NS & NS \\
\hline
\end{tabular}

\section{DISCUSSION}

1. Discussion on the Disease

The entity of Cervical Erosion is compared to Garbhashaya Mukha Vrana as mentioned earlier. The etymology of Vrana goes as, "Vrana gatra vichurnane"3. This means any pathology causing vichurnana, i.e., the denudation or destruction of the part of the body is taken as Vrana. This is similar to the pathology of Cervical Erosion characterized by denudation or destruction of Squamous epithelium and replacement by Columnar Epithelium. Further, the following correlation establishes the type of vra$n a$ w.r.t Dosha and the Dhatu, and accordingly, Cervical erosion is Correlate to Vata Kaphaja ${ }^{4}$-Mamsa gata Garbhashaya Mukha Vrana ${ }^{5}$

\section{Vatakaphaja Garbhashaya Mukha Varana Lakshanas}

Lakshanas due to Vata

Aruna Varna Vrana,

Vedana in the Kati - Udara, Kandu Yukta Srava

Maithun Asahishnuta.

\section{Lakshanas due to Kapha} Shukla Sheeta, Guru, Paandu, Pichchila,

2. Discussion on the Procedure and mode of action: Yoni Varti is one among the Bahirparimarjana Chikitsa Indicated for Twak and Mamsagata Rogas. to bring about the desired therapeutic action, directly targeting the site of pathology. Suppositories form a major part of the Vaginal Drug Delivery System (VDDS)

Vaginal Drug Delivery System (VDDS): The vagina, unlike other systems like buccal or gastrointestinal, is highly dynamic with respect to its physiology

\section{Mamsa gata Vrana Lakshanas}

Sandra, Shweta, Pichchila, Sarpiprakasha Srava.

\begin{tabular}{|c|c|c|}
\hline Drugs & Pradhana Karma & \\
\hline & Doshaghnata & Rogaghnata \\
\hline Kushta ${ }^{6}$ & Vatakaphahara & Vrana, Kandu Kotha-pidakanasha \\
\hline$A r k a^{7}$ & Vatahara & Krimi hara, Vranashodana \\
\hline Pippali $^{8}$ & Vatakaphahara & Shoolahar. \\
\hline Saindhava Lavana ${ }^{9}$ & Vatakaphahara & Vranahara, Udara, shulahara \\
\hline Aja Mutra ${ }^{10}$ & Tridoshahara specifically Vatakaphahara & Krimi hara \\
\hline
\end{tabular}


Samprapti Vighatanaby active principles of Drugs

\begin{tabular}{|l|l|l|}
\hline Active Principle & Mode of Action & Result \\
\hline Tannin & Coates the orifices of mucous secreting glands, reducing its secretion & Stypticaction \\
\hline $\begin{array}{l}\text { Cynaropicrin, saussurine, } \\
\text { uscherin, amyrin, piplasterol, } \\
\text { Essential minerals }\end{array}$ & $\begin{array}{l}\text { Inhibit TNF } \alpha \text { from lipopolysaccharide-, inhibit nitric oxide produc- } \\
\text { tion in lipopolysaccharide. }\end{array}$ & Anti-Inflammatory \\
\hline $\begin{array}{l}\text { Aromatic oils, giganteol, } \\
\text { calotropin, piperin, piplartine }\end{array}$ & $\begin{array}{l}\text { Affect the cell wall synthesis and cell membrane function of mi- } \\
\text { crobes and ultimately affect their survival. }\end{array}$ & $\begin{array}{l}\text { Anti-microbial, } \\
\text { Anti-bacterial }\end{array}$ \\
\hline $\begin{array}{l}\text { Costunolide, calotoxin, } \\
\text { piperine }\end{array}$ & Peripheral inhibition of prostaglandin synthesis. & Analgesic \\
\hline
\end{tabular}

Tannin ${ }^{11}$, one of the major components of Kushta, being a phenolic functional group produces tannic acid which coats the orifices of mucous secreting glands, reducing its secretion, thus bringing about styptic action. Cynaropicrin and saussurine of Kushta, ${ }^{12}$ Uscherin and amyrin of Arka, ${ }^{13}$ Piplasterole and sesamin of Pippali, ${ }^{14}$ Essential minerals of Saindhava Lavana and Ajamutra are anti-inflammatory. They act by inhibiting TNF $\alpha$ from lipopolysaccharidestimulated murine macrophage and also inhibit nitric oxide production in lipopolysaccharide activated murine macrophages. ${ }^{15}$ Aromatic oils of Kushta and Pippali, giganteol of Arka are antimicrobial. Calotropin of Arka, Piperine and piplartine of Pippali, essential minerals of Saindhava Lavana, Uric acid levels of Aja mutra act as antibacterial, by affecting the cell wall synthesis and cell membrane function of microbes, which ultimately affect their survival. Thus, the main action of the active principles of Kushtadi Yoni Varti are anti-inflammatory (combats primitive cell pathology), Styptic, anti-microbial, anti-bacterial, analgesic), thus helping in healing of erosion.

\section{Discussion on Observations}

The age group $18-26$ years is the period when the woman is sexually most active as well as inactive childbearing age fluctuating levels of oestrogen is a peak in the reproductive age. ${ }^{1}$ Non-vegetarian food, Madhura Ahara and curd intake and Diwaswapan causes Kapha Vriddhi and Agnimandya, aggravating the condition. Most of the patients were of Kaphavata Prakruti, establishing the fact that they are more prone to Kapha Vataja disorder. $90 \%$ of patients were multigravida, Majority had FTND and more frequent intercourse. So, a greater number of deliver- ies make a female more prone to suffer from repeated vaginal infections. Repeated p/v examination, intrusion by instruments, unsterile conditions around the lady during the time of delivery, intercourse lead to Extensive intrusion of the vagina and cervix and result as a potential cause for Pathology. Thick-white mucoid discharge is a typical nature of discharge in cases of Cervical Erosion and the Vata kaphaja Vrana.

\section{Discussion on Results}

The Highly significant effect of the treatment in Group A is due to the Doshaghnata and Rogaghnata of the Dravyas of Varti. The Kashaya rasa of Aja Mutra Exhibitsstambhana, Sangraha, Shoshana, Kledashoshaka and Kaphanashaka properties which along with, Ruksha Guna of Kushta and Arkaare responsible for relief from Srava. The high content of Tannins in Ajamutra helps in the reduction of excess discharge. The cause of Dourgandha or foul smell can be attributed to increased cell debris secondary to inflammation in the vaginal area. The Tikshna, Ushna Guna of Kushta and Arka brings about Lekhana of this debris. Kushta and Pippali predominantly contain aromatic oil, which prevents the possibility of thriving micro-organisms and thus helps in reducing the offensive odour in the vaginal environment.

The Kleda Pradhyanya and Snigdhata of the Yoni Srava are mainly responsible for the Lakshana of Kandu. The Katu Rasa of Kushta, Arka and Pippali and Ruksha - Tikshna -Ushna Guna of Kushta and Arka are responsible for Shoshana of Srava and thereby reduce the Kledatva and Snigdhata of Srava. This ultimately brings about relief from Kandu. The sesamine and the piplartine active principles of Pip- 
pali brings about the scarifying action and reduce the moisture content in the vaginal discharge and thus relieving itching sensation. Katishoola and Udara shoola are a direct result of chronic or persistent irritation of the cervix caused by excessive vaginal discharge. The referred pain from the cervical area or due to cervical irritation is perceived at the lower back region or upper and lower sacral vertebral area. So, when the Srava is reduced, the persistent irritation to the cervix also resolves, further resolving Katishoola and Udara Shoola. The exclusive Shoola Hara action of Pippali as told in the classics substantiates the relief from cervical tenderness. Accordingly, piperine acts as a local analgesic. Vrana Hara action of Kushta and Saindhava along with Vrana Shodhana brought in by Arka contributes towards reducing the degree of erosion. The Exfoliation of Epithelial cells helps in reversing the Samprapti.

The significant result in group B is due to the effect of Nidana Parivarjana in terms of Ahara specifically.

\section{CONCLUSION}

Kushtadi Yoni Varti, a Sthanika Chikitsa modality has a highly significant effect in the treatment of Cervical Erosion. This Clinical trial has to be done on a large population for the establishment of the efficacy.

\section{REFERENCES}

1. Howkins and Bourne Edited by Padubidri and Shirish, Shaw's Textbook of Gynaecology, Diseases of Cervix, Elsevier Publication, New Delhi,2004, $13^{\text {th }}$ Edition, Chapter 24, pp- 508, pg- 314-317.

2. Agnivesha, Charaka Samhita, with Ayurveda Dipika Commentary by Chakrapanidatta, Edited by Vaidya Yadavji Trikamji Acharya, Chaukhamba Surabharathi Prakashana, Varanasi, Reprint - 2011, Chikitsa Sthana, Chapter 30, Verse109,110Pp-738, Pg- 639

3. Sushruta, Sushruta Samhita, with the Nibandhasangraha Commentary of Sri Dalhanacharya, edited by Vaidya Yadavji Trikamji Acharya, Chaukhambha Surbharati Prakashana, Varanasi, Reprint 2010, Chikitsa Sthana, $1^{\text {st }}$ Chapter, Verse 6, pp-824, pg- 396

4. Sushruta, Sushruta Samhita,with the Nibandhasangraha Commentary of Sri Dalhanacharya, Edited by Vaidya Yadavji Trikamji Acharya, Chaukhambha
Surbharati Prakashana, Varanasi, Reprint 2010, Sharira Sthana, Chapter 3, Verse 19, pp-824, pg-352

5. Sushruta, Sushruta Samhita, with the Nibandhasangraha Commentary of Sri Dalhanacharya, Edited by Vaidya Yadavji Trikamji Acharya, Chaukhambha Surbharati Prakashana, Varanasi, Reprint 2010, Sutra Sthana, Chapter 23, Verse 7, pp-824, pg- 108,109

6. Bhava Mishra, commentary by Padmshri K.C Chunekar, Edited by Late Dr G.S Pandey, Bhavaprakasha Nighantu, Chapter 1, Haritakyadi Varga, Chaukambha Bharati Academy, Varanasi, 2015, Pg 87

7. Bhava Mishra, commentary by Padmshri K.C Chunekar, Edited by Late Dr G.S Pandey, Bhavaprakasha Nighantu, Chapter 2, Guduchyadi Varga, Chaukambha Bharati Academy, Varanasi, 2015, Pg 290

8. Bhava Mishra, commentary by Padmshri K.C Chunekar, Edited by Late Dr G.S Pandey, Bhavaprakasha Nighantu, Chapter 1, Haritakyadi Varga, Chaukambha bagrati academy, Varanasi, 2015, Pg 24

9. Bhava Mishra, commentary by Padmshri K.C Chunekar, Edited by Late Dr G.S Pandey, Bhavaprakasha Nighantu, Chapter 1, Haritakyadi Varga, Chaukambha bagrati academy, Varanasi, 2015, Pg 149

10. Prof P.V Sharma, Dravya Guna Vignana, Vol, Chaukhambha Bharati, Academy, 2005, pp 873.

11. www.ansci.cornell.edu/plants/toxicagents/tannin.html

12. www.stmconnect.com/cocam/content/1/1/4

13. www.icmr.nic.in/annual/2005-06/dmrc/ale.

14. www.ncbi.nlm.nih.gov/pubmed/23434420

15. www.ayusoft.cdac.in/pshome/apps/en/src/Articles//Ku shtha.htm

\section{Source of Support: Nil \\ Conflict of Interest: None Declared}

How to cite this URL: Sindhu Umesh et al: Randomised Controlled Clinical Study Of Kushtadi Yoni Varti On Cervical Erosion. International Ayurvedic Medical Journal \{online\} 2021 \{cited November 2021\} Available from: http://www.iamj.in/posts/images/upload/3157 3162.pdf 